\title{
Does two-piece PPI provide improvement in patient-partner quality of life?
}

\author{
Engin Özbay ${ }^{1}$, Remzi Salar ${ }^{2}$, Halil Ferat Öncel ${ }^{2}$ \\ ${ }^{1}$ SBU Istanbul Kanuni Sultan Süleyman Research and Training Hospital, Department of Urology, Turkey; \\ 2 SBU Sanlıurfa Mehmet Akif İnan Research and Training Hospital, Department of Urology, Turkey.
}

\begin{abstract}
Summary Objective: The aim of this study is to retrospectively examine patient-partner satisfaction and changes in quality of life due to two-piece penile prosthesis implantation (PPI). There is no data about partner Quality of Life (QoL) related to two-piece PPI in the literature. Material and Methods: SF 36 scale and modified Erectile Dysfunction Inventory of Treatment Satisfaction (EDITS), which were filled before two-piece PPI and at the sixth postoperative month follow-up by male patients $(n=45)$ and female partners $(n=45)$, were evaluated.

Results: We found patient-partner satisfaction rates as $80 \%$ and $86 \%$ respectively. The changes in all mean scores of SF 36 (mean total score, mean physical health score and mean mental health score) were statistically significant $(p<0.01)$.

Again, the differences between all mean scores of SF 36 according to the level of patient-partner satisfaction were statistically significant $(p<0.01)$.

Conclusions: Two-piece PPI is an important option for ED treatment. It provides significant improvement in patient-partner QoL with high treatment satisfaction.
\end{abstract}

KEY WORDS: Two-piece penile prosthesis implantation; Patientpartner satisfaction; Quality of life.

Submitted 13 December 2020; Accepted 2 January 2021

\section{INTRODUCTION}

Erectile dysfunciton (ED) is a benign disease and it affects physical and psychosocial health condition. It has an important effect on patient's and partner's quality of life. ED treatment consists of three steps. Lifestyle modification and risk factor modification should be performed either before or together with ED treatment. Oral phosphodiesterase 5 inhibitors (PDE5I), vacuum erection device, topical/intraurethralal prostadil, and shock wave therapy are used in the first-line treatment.

In the second-line treatment, intracavernosal injection of alprostadil or combination therapy is applied. For the third-line treatment, penile prosthesis implantation (PPI) is available (1). Treatment failure is seen in approximately $80 \%$ of patients due to their discontinuation with firstline and second-line treatment (2). PPI is therefore an important option for patients that do not comply with or respond to these therapies.

In the treatment of ED, PPI is a method that provides highest patient and partner satisfaction among all treatment options (3). In the literature, the rate of patient and partner satisfaction varies between 70 and $87 \%$ (4).The high satisfaction of the couples also increases the quality of their sexual lives (5).

Short form (SF) 36 scale is used to measure patient's quality of life (QoL). It has both easy and short applicability. Since it is not specific to any disease group, it is recommended to be used in all physical disease groups to determine QoL, to reveal the psychosocial aspect of the disease and to determine the change in treatment. (6). Ure et al. evaluated patients' QoL with SF 36 scale and observed that it was significantly increased after PPI compared to the preoperative period (7). However, in studies about patient QoL who underwent PPI, partner QoL was not mentioned much (8).

In the current study, patients that did not respond to first-line and second-line treatments, and therefore underwent two-piece PPI were evaluated. The changes in QoL with satisfaction levels of patients' and partners' were retrospectively examined.

\section{MATERIALS AND METHOdS}

The data of 61 patients that underwent PPI due to organic ED between March 2016 and March 2020 were retrospectively reviewed. In total 45 patients and 45 partners agreed to voluntarily participate in the study. Inclusion criteria: male patients with placement of two-piece PPI and their female partners, having not received a psychiatric diagnosis and treatment before PPI in their anamnesis, postoperative follow-up period of at least one year. Depending on the medical history and socioeconomic status of the patients, the type of prosthesis to be applied was decided. The patients were informed about possible intraoperative and postoperative complications. Two-piece prosthesis implantation was performed under spinal anesthesia. In the perioperative period, the penoscrotal region was mechanically cleaned using chlorhexidine alcohol for $10 \mathrm{~min}$. All operations were performed with a penoscrotal incision. Dual antibiotics (ciprofloxacin and amoxicillin-clavulanic acid) were continued for two weeks after hospital discharge. The patients were trained to use the prosthesis after one month and were allowed to use the prosthesis after six weeks.

No conflict of interest declared. 
SF-36 scale was respectively administered before PPI and at the postoperative sixth month follow-up by face-toface interviews. Modified Erectile Dysfunction Inventory of Treatment Satisfaction (mEDITS) was filled at the postoperative sixth month, too.

\section{Statistical analysis}

IBM SPSS Statistics 22.0 program was used for statistical analysis while evaluating the findings obtained in the study. While evaluating the study data, in addition to descriptive statistical methods (Mean, Standard deviation), Paired Samples t test was used for the pre-post comparisons of the parameters showing normal distribution. Student $t$ test was used for comparisons between the two groups. Significance was evaluated at the $p<0.05$ level.

\section{REsULTS}

The mean age of 45 male patients was $49.7( \pm 12)$ years, and the mean age of their female partners was 42.3 $( \pm 10)$ years. The mean follow-up period was $40( \pm 23)$ months. Diabetes mellitus (\%42), radical prostatectomy (\%14), penile vascular disease (\%38) and Peyronie disease (\%6) were the etiology of ED. Since there was no patient that presented to the hospital with priapism, we did not include it in the table. The American Medical Service $\left(\right.$ AMS $^{\circledR}$ ) two-piece penile prosthesis was implanted in 45 patients. The mean length of hospital stay was three days. In the early postoperative period, one patient developed scrotal hematoma and one developed soft tissue infection due to negligent antibiotic use. In two patients, penoscrotal pain lasted for two months postoperatively. At the fourth postoperative month, mechanical damage was observed in the two-piece penile prosthesis of one patient. The patient-partner satisfaction rates were evaluated using mEDITS at the sixth month. According to the results, $80 \%$ of the patients $(\mathrm{n}=36)$ and $86.7 \%$ of the partners $(n=39)$ expressed satisfaction with PPI while $20 \%$ of the patients $(n=9)$ and $13.4 \%$ of the partners $(n=6)$ were dissatisfied with the procedure. SF 36 scale can also be evaluated under two main subscales as "Physical Health" and "Mental Health". Table 1 shows the evaluation of SF-36 scores before and after PPI. According to mean total score before PPI, the increase seen in mean total score after PPI was statistically significant $(\mathrm{p}<0.01)$ in patients. And also the increases seen in mean physical health score and mean mental health score after PPI were statistically significant $(p<0.01)$.

\section{Table 1.}

Evaluation of SF-36 scores before and after PPI.

\begin{tabular}{|l|c|c|c|c|}
\hline & & $\begin{array}{c}\text { Before PPI } \\
\text { Mean } \pm \text { SD }\end{array}$ & $\begin{array}{c}\text { After PPI } \\
\text { Mean } \pm \text { SD }\end{array}$ & p \\
\hline Male patients & Physical health & $63.25 \pm 9.35$ & $82.11 \pm 16.63$ & $0.001^{* *}$ \\
& Mental health & $58.35 \pm 13.65$ & $81.89 \pm 18.55$ & $0.001^{* *}$ \\
& Total scores & $60.80 \pm 10.69$ & $82.01 \pm 17.45$ & $0.001^{* *}$ \\
\hline Female partners & Physical health & $62.06 \pm 10.43$ & $84.52 \pm 15.21$ & $0.001^{* *}$ \\
& Mental health & $55.34 \pm 13.92$ & $80.09 \pm 19.52$ & $0.001^{* *}$ \\
& Total scores & $58.69 \pm 11.69$ & $82.31 \pm 17.35$ & $0.001^{* *}$ \\
\hline \multicolumn{3}{|l|}{ Paired Samples t test. **p $<0.01}$.
\end{tabular}

Table 2.

Evaluation of SF-36 scores according to satisfaction status.

\begin{tabular}{|l|c|c|c|c|}
\hline & & $\begin{array}{c}\text { Unsatisfied } \\
\text { Mean } \pm \text { SD }\end{array}$ & $\begin{array}{c}\text { Satisfied } \\
\text { Mean } \pm \text { SD }\end{array}$ & p \\
\hline Male patients & Physical health & $52.33 \pm 13.47$ & $89.56 \pm 4.61$ & $0.001^{* *}$ \\
& Mental health & $46.42 \pm 8.23$ & $90.77 \pm 3.55$ & $0.001^{* *}$ \\
& Total scores & $49.37 \pm 10.67$ & $90.16 \pm 3.83$ & $0.001^{* *}$ \\
\hline Female partner & Physical health & $49.10 \pm 10.63$ & $89.97 \pm 4.96$ & $0.001^{* *}$ \\
& Mental health & $35.38 \pm 10.17$ & $86.96 \pm 7.96$ & $0.001^{* *}$ \\
& Total scores & $42.24 \pm 10.39$ & $88.47 \pm 6.46$ & $0.001^{* *}$ \\
\hline Paired Samples t test. ${ }^{* *}$ p $<0.01$. & & \\
\hline
\end{tabular}

According to Table 1, the statistical results of the partners were similar to the statistical results of the patients $(p<0.01)$. Table 2 shows the evaluation of SF-36 scores according to satisfaction status. The mean total score of the satisfied group after PPI was significantly higher than the dissatisfied group $(p<0.01)$. Again mean mental health score and mean physical health score of the satisfied group after PPI were significantly higher than the dissatisfied group $(\mathrm{p}<0.01)$. According to Table 2 , the statistical results of partners showed to be similar to the statistical results of the patients $(\mathrm{p}<0.01)$.

\section{Discussion}

Two-piece prostheses are preferred in patients who have undergone or are scheduled to undergo organ transplantation in the pelvic region, those with a history of radical pelvic surgery or pelvic radiotherapy, and cases that pose difficulty in terms of reservoir placement in the Retzius region (9). Other reasons for the preference of two-piece prostheses include their simple application, which makes it easier for the physician to guide the patients in terms of their use and also the full cost coverage of a twopiece penile prosthesis by Turkish Social Security Institution (10). Lastly, in socioeconomically and socioculturally developed countries, three-piece prostheses are the most preferred type since they can mimic erection as close to nature as possible and have a more cosmetic appearance (11). The disadvantages of three-piece prostheses are that mechanical damage complicates cases and they are more expensive than other types of prosthesis (12). In this study, we used two-piece prostheses for their ease of use and socioeconomic reasons, as well as due to the presence of radical pelvic surgery history in the study population.

The most common cause of dissatisfaction after PPI is shortening of the penile length, which is generally 1 to 2 $\mathrm{cm}$ (13). In a previous study, the satisfaction rate of patients that underwent prosthesis implantation due to priapism was observed to be $60 \%$ due to the complaint of penile shortening (14). Patients with Peyronie's disease that undergo PPI may require additional surgical procedures to maintain penile length (15). Other reasons for patient dissatisfactions include the development of postoperative infections, mechanical damage, erosion, penile pain, short prosthesis, and soft glans syndrome (13). Presence of DM, spinal cord injury, revision surgery, steroid-dependent patients and complicated PPI procedure increase the risk of postop infection. When prosthe- 
sis infection develops, all elements of the prosthesis are removed (16). Infection treatment is applied. If the new prosthesis is implanted 3-6 months later, the procedure becomes very difficult and the penis becomes shorter.

To prevent this complication, salvage procedure can be performed. While removing the prosthesis, mechanical cleaning is applied to the infected tissues with antibiotic solutions in the same session. New PPI is applied in the same session or postponed after 6-8 weeks (17).

In our study three patients were dissatisfied with the shortening of their penis length, two patients used oral ciprofloxacin for two months to relieve penile pain.

The penile prosthesis of one patient was replaced due to mechanical damage. Soft tissue infection was observed in one patient and was suppressed with intravenous antibiotherapy.

The unnatural appearance of the prosthesis and the unnatural sensation may also be the cause of dissatisfaction for patient and partner (18). Sexual desire disorder, sexual arousal disorders, orgasm and ejeculation problems can also be the cause of dissatisfaction with the patient and partner related to penile prosthesis implantation (19). In the current study three patients were dissatisfied due to ejaculation disorder, two patients and four partners complained of not being fully satisfied with orgasm and one couple was dissatisfied due to the unnatural appearance of the penis.

In a study conducted with two-piece prostheses, the patient-partner satisfaction rates were observed to be over $80 \%$ (20). CCayan et al. conducted a PPI study with 883 patients and reported no statistically significant difference in patient-partner satisfaction rates related to two- and three-piece prostheses, while their satisfaction rates were higher than one-piece prostheses (21). In our study, we calculated the patient and partner satisfaction rates as $80 \%$ and $86 \%$, respectively, which is consistent with the literature.

Ozbay et al. in a study observed that patients with erectile dysfunction due to organic origin disease had sexual dysfunction together with their female partners and the sexual dysfunction of couples improved together after PPI (19).

Studies have repeatedly shown that PPI positively affects patients' QoL, perceived quality of the couple relationship, partner satisfaction, body image, the relationship with the outside world, and the satisfaction with the implant function $(22,23)$. In addition, in a study where the patient follow-up period was at least 15 years, it was found that $60 \%$ of the patients still used penile prostheses, satisfaction was high, and the QoL results were sufficient (8). In this study, patient QoL was not at a healthy level before PPI. The significant increase in patients' mean total score, mean physical health score and mean mental health score after PPI indicated an improvement in patient QoL. QoL of satisfied patients was also at a high level.

Sexual dysfunction of the female patient negatively affects QoL (24). A high rate of sexual dysfunction was observed with the decrease in QoL of female patients with organic origin diseases, and it was observed that the same findings were also observed in the male partners of the patients (25-28). Successful treatment of female patients' diseases such as hypertension, diabetes, pituitary insufficiency, hypothyroidism and breast cancer improves their sexual dysfunction and QoL $(29,30)$. There are many studies in the literature that evaluate QoL of male patients with penile prostheses, but findings evaluating QoL of female partners could not be observed in these studies $(8,22,23)$. In this study, partners' QoL was not at a healthy level before PPI. The significant increase in partners' mean total score, mean physical health score and mean mental health score after PPI indicated an improvement in partner QoL. Satisfied partner QoL was also at a high level.

\section{Conclusions}

High level of patient-partner satisfaction for ED therapy is achieved with the two-piece PPI. In our study, patientpartner QoL was not at a healthy level before PPI. But it was observed that patient-partner QoL increased similarly after PPI. Satisfied patient-partner QoL was also at a high level.

\section{Ethics COMMITTEe APPROVAL}

Harran University Faculty of Medicine Ethical Committee approved. Consent form and permission was obtained from all patients who participated in the study.

\section{REFERENCES}

1. Hatzimourotidis K, Guiliano F, Moncada I, et al. EAU guidelines on males sexual dysfunction. 2016; p: 14-22.

2. Gümüş BH, Albaz AC. Erektil disfonksiyon tedavisinde penil protez implantasyonun uzun dönem klinik sonuçları. Androl Bul. 2017; 19:117-122.

3. Efesoy O, Özbay E, Tek M, et al. Longterm outcomes and couple's satisfaction with three-piece inflatable penile prosthesis surgery in the treatment of erectile dysfunction. Türkiye klinikleri J MedSci, 2010; 30:1965-70.

4. Levine LA, Estrada CR, Morgentaler A. Mechanical reliability andsafety of and patient satisfaction with the Ambicor inflatable penileprosthesis: results of a 2 center study. J Urol. 2001; 166: 932-7.

5. Barton GJ, Carlos EC, Lentz AC. Sexual quality of life and satisfaction with penile prosthesis. Sex Med Rev. 2019; 7:178-188.

6. Newman SP. Psychosocial measures in musculoskeletal trials. J Rheumatol. 1997; 24:979-84.

7. Ure I, Ozen A, Can C. Life quality change after inflatable penile prosthesis implantation. Aging Male. 2020; 23:362-368.

8. Chierigo F, Capogrosso P, Dehò F, et al. Long-term follow-up after penile prosthesis implantation-survival and quality of life outcomes. J Sex Med. 2019;16:1827-1833.

9. Morey AF. Re: Ambicor 2-piece inflatable penile prosthesis: who and how? J Urol. 2018; 200:691-692.

10. Ozan T, Karakeçi A, Pirinçci A, et al. Iki parçalı sisirilebilir penil protez cerrahisine ait klinik sonuçlar ve hasta memnuniyetinin degerlendirilmesi. F.Ü.Sag.Bil.Tıp.Derg. 2018; 32:27-30.

11. Usta MF. Penil protez cerrahisinde yenilikler: 2016 güncelleme. Androloji bülteni. 2016; 18 :212-216. 
12. Esengen S, Nalbant I, Öztürk U, et al. Comparison of penile prosthesis methods: which is more successful? J Clin Anal Med. 2017; 8:421-4.

13. Küçük E, Bindayı A. Penil protez cerrahisi komplikasyonları ve basaçııma yöntemleri. And Bült. 2016; 18:25-29.

14. Zacharakis E, Garaffa G, Raheem A et al. Penile prosthes insertion in patients with refractory ischaemic priapism: early vs delayed implantation. BJU Int 2014; 114:576-581.

15. Barrett-Harlow B, Clavell-Hernandez J, Wang R. New developments in surgical treatment for penile size preservation in Peyronie's disease. Sex Med Rev. 2019; 7:156-166.

16. Mulcahy JJ. Current approach to the treatment of penile implant infections. Ther Adv Urol. 2010; 2:69-75.

17. Mellon MJ, Broghammer JR, Henry GD. The Mulcahy Salvage: Past and Present Innovations. J Sex Med. 2015; 12 (Suppl 7):432-6.

18. Salama N. Satisfaction with the malleable penile prosthesis among the couples from the Middle East- is it different from that reported elsewhere? Int J Impo Res. 2004; 16:175-180.

19. Özbay E, Aydın A, Salar R, et al. Sexual experiences between partners after penile prosthesis: Who is more satisfied? Andrologia. 2020; 52:e13461.

20. Lux M, Reyes-Vallejo L, Morgentaler A, Levine LA. Outcomes and satisfaction rates for the redesigned 2-piece penile prosthesis. $J$ Urol. 2007; 177:262-6.

21. Cayan S, Ascl R, Efesoy O, et al. Comparison of long-term results and couples's satisfaction with penile implant types and brands: lessons learned from 883 patients with erectile dysfunction who underwent penile prosthesis implantation. J Sex Med. 2019; 16:1092-1099.

22. Carvalheira A, Santana R, Pereira NM. Why are men satisfied or dissatisfied with penile implants? A mixed method study on satisfaction with penile prosthesis implantation. J Sex Med. 2015; 12:2474-80.

23. Caraceni E, Utizi L. Questionnaire for the evaluation of quality of life after penile prosthesis implant: Quality of Life and Sexuality with Penile Prosthesis (QoLSPP). To what extent does the implant affect the patient's life? J Sex Med 2014; 11:1005-1012.

24. Buster JE. Managing female sexual dysfunction. Fertil Steril. 2013; 100:905-15.

25. Tutoglu A, Boyaci A, Koca I, et al. Quality of life, depression, and sexual dysfunction in spouses of female patients with fibromyalgia. Rheumatol Int. 2014; 34:1079-1084.

26. Bilgic D, Gokyildiz S, Kizilkaya Beji N, et al. Quality of life and sexual function in obese women with pelvic floor dysfunction. Women Health. 2019; 59:101-113.

27. Radoja I, Degmecic D. Quality of life and female sexual dysfunction in Croatian women with stress-, urgency- and mixed urinary incontinence: results of a cross-sectional study. Medicina (Kaunas). 2019; 55:240.

28. Nappi RE, Cucinella L, Martella S, et al. Female sexual dysfunction (FSD): prevalence and impact on quality of life (QoL). Maturitas. 2016; 94:87-91.

29. Basson R. Female sexual dysfunction in hypopituitarism. Lancet. 2007; 70(9589):737.

30. Basson R. Sexuality in chronic illness: no longer ignored. Lancet. 2007; 369(9559):350-2.

\section{Correspondence}

Özbay Engin, MD (Corresponding Author)

nozbay63@gmail.com

SBU Istanbul Kanuni Sultan Süleyman Research and Training Hospital, Department of Urology, Istanbul (Turkey)

Salar Remzi, MD

Öncel Halil Ferat, MD

SBU Sanluurfa Mehmet Akif İnan Research and Training Hospital, Department of Urology, Sanliurfa (Turkey) 